\title{
A guerra dos pneus: a controvérsia entre Brasil e Comunidades Europeias sobre o comércio internacional de pneus usados
}

\section{War of Tires: the Dispute between Brazil and the European Communities on the International Trade of Used Tires}

\author{
Lília LUZ* \\ Daniel DURANTE**
}

\begin{abstract}
RESUMO
A Organização Mundial do Comércio (OMC) possui em sua estrutura um órgão para dirimir conflitos relativos à manutenção do livre-comércio, que é o Órgão de Solução de Controvérsias (OSC). Neste trabalho, analisa-se o contencioso "Brasil - Medidas que afetam a importação de pneumáticos reformados", veiculado na imprensa brasileira sob o epíteto "A guerra dos pneus", ocorrido entre os anos de 2005 e 2007 junto ao aludido órgão. Trata da imposição, por parte do Brasil, de medidas restritivas à entrada de pneus usados ou reformados. A proibição não se estendia aos países do MERCOSUL em virtude de uma decisão do Tribunal Arbitral deste bloco econômico, que obrigou o Brasil a permitir a entrada de pneus usados ou reformados destes países. O Brasil alegou que tal medida se adequava ao permitido pelo Artigo XX do Acordo Geral de Tarifas e Comércio (GATT), mas as Comunidades Europeias (CE) entenderam se tratar de medida restritiva ao comércio de cunho meramente protecionista. Objetiva-se investigar as motivações ambientais e comerciais de tal medida. Observou-se que o Brasil realmente possuía motivos ambientais para a imposição das medidas e que as CE objetivavam utilizar aquele país como receptor de seus resíduos de pneus, os quais, por força de rígida legislação interna europeia, não poderiam mais ser descartados em seus aterros sanitários.
\end{abstract}

Palavras-chave: comércio internacional; meio ambiente; pneumáticos; protecionismo; relações internacionais.

\footnotetext{
ABSTRACT

The World Trade Organization (WTO) has in their structure a body to settle disputes relating to the maintenance of free trade, which is the Dispute Settlement Body (DSB). In this paper, we analyze the controversial "Brazil - Measures affecting the importation of restored tires", conveyed in the Brazilian press under the epithet "The War of the tires," occurred between the years 2005 and 2007 within the

"Mestra em Desenvolvimento e Meio Ambiente (UFRN). E-mail: lilisluz@gmail.com

** Doutor em Lógica e Filosofia da Ciência (UNICAMP). Professor do Departamento de Filosofia da Universidade Federal do Rio Grande do Norte (UFRN).

E-mail: durante@ufrnet.br
} 
aforementioned body. This is a Brazilian imposition of measures restricting the entry of used or restored tires. The ban was not extended to the MERCOSUR countries due to a decision of the Arbitration Court of the economic bloc, which led Brazil to allow the entry of used and restored tires in these countries. Brazil has argued that this would suit what was allowed by the Article XX of the General Agreement on Tariffs and Trade (GATT), but the European Communities (EC) understood this as a merely protectionist restrictive measure to trade commerce. The objective here is to investigate whether the adoption of such a measure had actually environmental motive or, on the other hand, sought trade protectionism. It was observed that Brazil really had grounds for the imposition of environmental measures and the EC aimed to use this country as the recipient of its waste tires, which, under rigid internal European legislation, could no longer be disposed in its landfills.

Keywords: international trade; environment; pneumatic; protectionism; international relations.

Por que vocês não sabem do lixo ocidental?

Não precisam mais temer

Não precisam da solidão

Todo dia é dia de viver

Por que você não verá meu lado ocidental?

Não precisa medo não

Não precisa da timidez

Todo dia é dia de viver... ${ }^{1}$

\section{Introdução}

Neste trabalho, será analisado o caso "Brasil - Medidas que afetam a importação de pneumáticos reformados", também veiculado na mídia sob o epíteto "A guerra dos pneus" e ocorrido entre os anos de 2005 e 2007, junto ao Órgão de Solução de Controvérsias (OSC) da Organização Mundial do Comércio (OMC).

Será feita, inicialmente, uma contextualização da problemática dos pneus no Brasil, explicitando, para começar, quais são as principais associações representativas e como elas se organizam, quais são as formas possíveis de destinação do pneu inservível e quais os riscos ambientais gerados pelo seu descarte inadequado.

A seguir, será apresentada ao leitor a linha do tempo do caso, que demonstra o seu desenrolar jurídico, para, enfim, empreender uma discussão acerca das suas implicações ambientais e econômicas, procurando, neste tópico, sempre que possível, apontar evidências que demonstrem como o meio ambiente foi tratado no caso concreto e qual a sua relevância para as discussões econômicas travadas em seu interior, no intuito de responder à pergunta que originou esta pesquisa - no contexto do comércio internacional propugnado pela OMC, o meio ambiente é utilizado de forma legítima pelos países, ou estes visam ao alcance de benefícios comerciais disfarçados?

O que poderia ser compreendido como uma disputa meramente jurídica, na realidade descortina um caso que traz consigo várias particularidades: o fato de haver um conflito geopolítico em cena, visto que se trata de uma disputa entre um país em desenvolvimento, do hemisfério sul, e um grande bloco de países desenvolvidos e historicamente em posição hegemônica, ${ }^{2}$ pertencentes ao hemisfério norte; o fato de a parte vencedora em primeira instância, as Comunidades Europeias, apelar para o órgão superior, demonstrando, assim, irresignação diante de uma decisão que em tese lhe beneficiou; a circunstância de o país reclamado se defender tanto no fórum da OMC quanto em outro tribunal internacional acerca da mesma questão e quase ao mesmo tempo; e, por fim, o fato de ambas as decisões, tanto a de primeiro grau quanto a de segundo, serem benéficas ao Brasil, país perdedor em primeira instância.

Para que se entenda melhor o nascimento e o deslinde da questão levada à $\mathrm{OMC}$, é preciso primeiro revisitar os temas que fundamentam a discussão, como

\footnotetext{
${ }^{1}$ Trecho da canção "Para Lennon e McCartney”, de Fernando Brant, Lô Borges e Márcio Borges.

${ }^{2}$ Segundo Le Preste (2005, p. 243), "A ecopolítica internacional foi e continua profundamente influenciada pela distribuição do poderio econômico no mundo. Ainda que as questões ambientais não implicassem sempre esta dimensão, os grandes problemas ambientais do planeta põem em questão as relações Norte-Sul e não podem ser compreendidas senão no contexto das reivindicações tradicionais dos países pobres".
} 
a problemática dos pneumáticos no Brasil, o papel das principais empresas envolvidas com a fabricação, comercialização e destinação final do produto, o desafio do tratamento, a normatização brasileira e a forma utilizada pelos países do hemisfério norte para tratar o tema.

Somente depois de vistos esses assuntos é que se passará ao tratamento da questão propriamente dita, pois que o entendimento daqueles é imprescindível para a compreensão exata dos termos da controvérsia em análise.

Quando da análise do caso, será feita uma abordagem resumida dos desdobramentos jurídicos para, a seguir, empreender uma discussão sobre o conteúdo material e teórico das discussões ambientais ocorridas no seu interior.

\section{A problemática dos pneumáticos no Brasil: as origens das medidas restritivas}

O pneumático ${ }^{3}$ é todo aquele artefato inflável constituído basicamente por borracha e materiais de reforço utilizados para rodagem em veículos. Quando esse produto nunca foi utilizado para rodagem, fala-se em pneu novo e, quando não se presta mais para uso em estradas, em inservível.

Aqueles ditos reformados são os que passaram por algum processo industrial a fim de aumentar a sua vida útil em meios de transporte, podendo tal mudança se dar por meio dos processos de recapagem, recauchutagem ou remoldagem. A recapagem é a substituição da banda de rodagem; a recauchutagem é a substituição da banda de rodagem e dos ombros e, por fim, a remoldagem é a substituição da banda de rodagem, dos ombros e dos flancos (paredes laterais) do pneumático.

Segundo a Associação Nacional da Indústria de Pneumáticos (ANIP, 2004), a produção brasileira de pneus teve início por ocasião da implantação do Plano Geral de Viação Nacional, de 1934, cuja concretização só se deu dois anos mais tarde, com a instalação da Companhia Brasileira de Artefatos de Borracha, ou simplesmente Pneus Brasil.
Nesse mesmo ano, foram fabricadas mais de 29 mil unidades do produto, sendo que durante o período de 1938 a 1941 ingressaram no país outras empresas fabricantes, de forma que aquela produção inicial subiu para 441 mil unidades.

Dados da ANIP (2004) dão conta de que, em 2010, as nove empresas associadas produziram 67,3 milhões de unidades, com um crescimento de $15 \%$ em relação à produção de 2009.

Segundo a Associação Brasileira do Segmento de Reforma de Pneus (ABR, 2011), a produção de pneus reformados a cada ano pelas 1.578 empresas existentes no setor se dá conforme os dados apresentados na tabela abaixo:

TABELA 1 - PRODUÇÃO ANUAL DE PNEUS POR TIPO DE VEÍCULO

\begin{tabular}{cc}
\hline TIPO DE VEÍCULO & PRODUÇÃO ANUAL \\
\hline Caminhão e ônibus & 7,6 milhões \\
Automóvel & 8 milhões \\
Motocicleta & 2 milhões \\
Fora-de-estrada e agrícola & 300 mil \\
Aviões & Número não fornecido \\
\hline
\end{tabular}

FONTE: ABR, 2011

\subsection{O ciclo dos pneumáticos no país}

Os pneus são itens indispensáveis à segurança do condutor de veículos, tendo sua vida útil determinada em função do tempo de uso, quilometragem rodada, condições das estradas, dentre outras.

No Brasil, segundo dados do Ministério do Meio Ambiente (MMA, s/ data), são descartados 40 milhões de pneus anualmente, o que, somado ao que já existe acumulado no país, representa um gigantesco passivo ambiental que precisa urgentemente de destinação adequada. Isso porque o pneu só pode ser reformado uma única vez para automóveis de passeio e até três vezes para caminhões, sendo o número formado pelos pneus de automóveis de passeio o mais representativo.

\footnotetext{
${ }^{3}$ As expressões pneumático e pneu serão consideradas, neste trabalho, como sinônimas.
} 
O ciclo desses produtos no país inicia com a reposição dos pneus e obedece à lógica apresentada na Figura 1 abaixo.

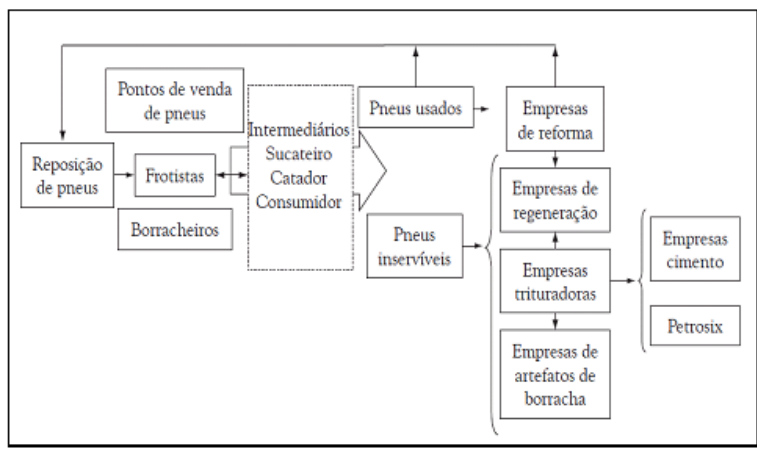

FIGURA 1 - Cadeia de reposição de pneus.

FONTE: MOTTA, 2008.
Outro fluxo demonstra em números a cadeia de destinação dos pneus. Ele foi obtido a partir de uma pesquisa realizada pelo Instituto de Pesquisas Tecnológicas (IPT), no ano de 2004, em que foram entrevistados 1.006 agentes envolvidos na geração e destinação de pneus: revendedores, borracheiros, sucateiros, ecopontos e laminadores (LEITE; SERRA, 2005).

Assim, a pesquisa indicou que, somente no ano de 2003, 22 milhões de pneus circularam entre os vários agentes envolvidos no ciclo, representando o mercado anual de reposição de pneus, com a ressalva de que se trata de um número de fluxo e não de estoque, pois que o mesmo pneumático pode ter sido contado mais do que uma vez (LEITE; SERRA, 2005).

Comparando-se os dados da pesquisa com aqueles provenientes do Ministério do Meio Ambiente, percebe-se que o número de pneus descartados é quase o dobro

(milhões de unidades)

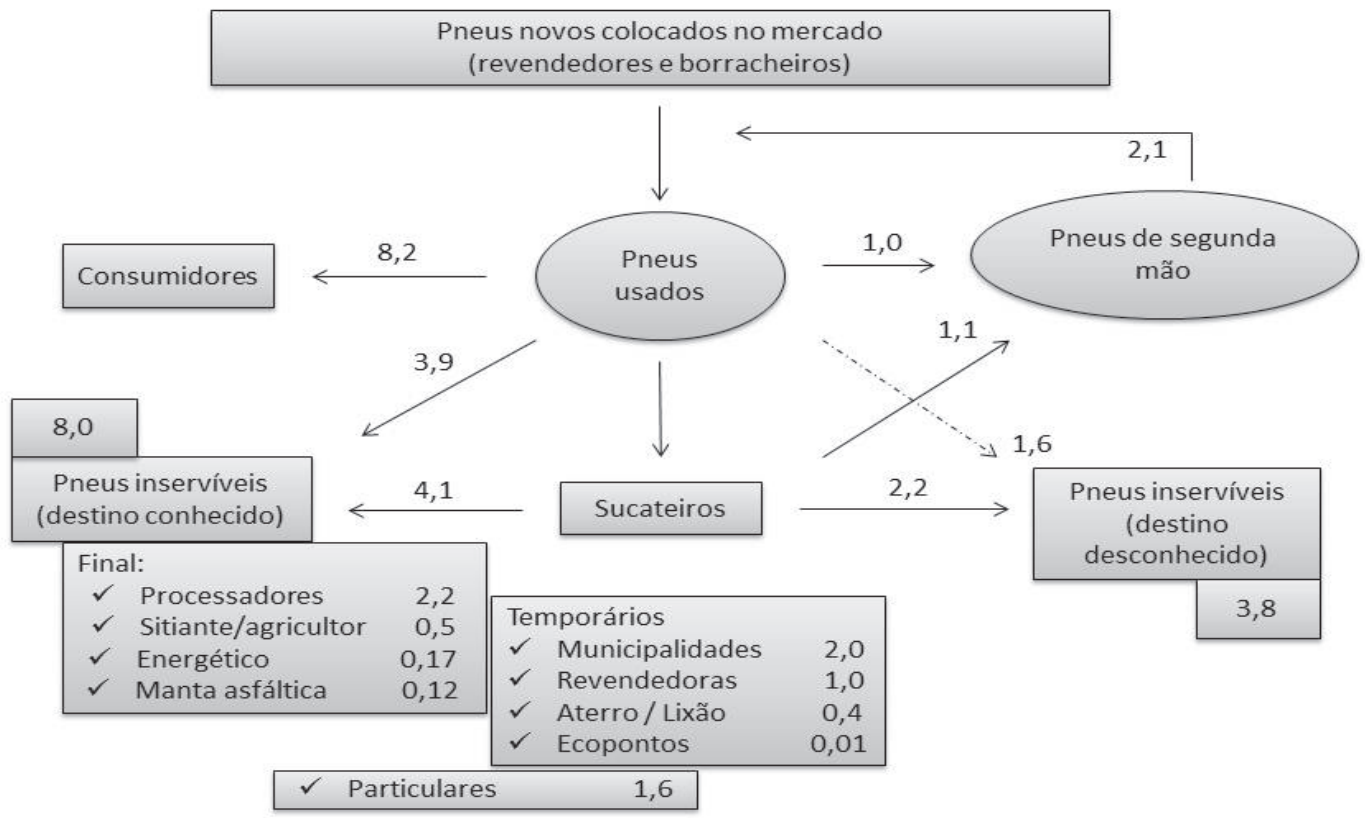

FIGURA 2 - Cadeia de destinação dos pneus novos.

FONTE: IPT, 2004, apud LEITE; SERRA, 2005. 
do total que circula dentro do fluxo (40 milhões descartados contra 22 milhões que circulam), evidenciando, assim, a carência de uma política institucionalizada de logística reversa ${ }^{4}$ desse resíduo no país e uma omissão dos agentes econômicos, sendo estes considerados tão responsáveis quanto o Estado, por força da Política Nacional de Resíduos Sólidos. ${ }^{5}$ Aliado a isso, contribuem para esse fato a deficiência na fiscalização do cumprimento da lei e a consequente falha na penalização do agente econômico.

Ainda,

é de se apontar a significativa quantidade de pneus usados retida pelos consumidores quando da troca por novos, número que é equivalente ao dos pneus inservíveis que têm destino conhecido. Destes e enquanto destino final, destacam-se os processadores que laminam ou trituram os pneus para diferentes finalidades e as pequenas quantidades aproveitadas para fim energético ou de pavimento asfáltico. Teoricamente, nos destinos temporários os pneus inservíveis estão acumulados e aguardando por uma destinação final, principalmente em locais de responsabilidade pública (municipalidades, aterro e lixão) e, secundariamente, privada (revendedoras) ou mista (ecopontos). Ressalte-se que a quantidade de pneus inservíveis apurada como tendo destinação desconhecida é praticamente a metade daquela cujo destino é conhecido (LEITE; SERRA, 2005, s/ p.).

\subsection{Os interesses econômicos envolvidos}

O segmento de venda de pneus no país pode ser vislumbrado a partir de duas óticas diametralmente opostas: a das empresas produtoras/importadoras de pneus novos e aquela das empresas reformadoras de pneus.

Os produtores/importadores de pneus novos formaram em 2002 a Associação Nacional das Indústrias de Pneumáticos (ANIP), a qual congrega nove grandes em- presas - Bridgestone-Firestone, Continental, Goodyear, Levorin, Maggion, Michelin, Pirelli, Rinaldi e Tortuga - e gera em torno de 165 mil empregos diretos e indiretos, segundo dados fornecidos pela própria Associação, atualizados até outubro de 2009.

AAssociação Brasileira do Segmento de Reforma dos Pneus (ABR, 2011) foi criada em 1985 e congrega três tipos de empresas - os reformadores de pneus; os fabricantes de matéria-prima para reforma de pneus e fabricantes de máquinas e equipamentos para reforma de pneus. Dados fornecidos pela organização indicam que o setor teve faturamento de quatro bilhões de reais nos três tipos - reforma, matéria-prima e equipamentos - , sendo composto por aproximadamente 1.578 reformadoras e 18 fornecedores de matéria-prima (15 nacionais e 3 multinacionais) e produziu 50.000 empregos diretos.

Pelos dados apresentados, observa-se que o segmento de produção de pneus novos é dominado por um grupo restrito de grandes empresas, de porte internacional, enquanto a produção de pneus reformados se dá por micro e pequenas empresas espalhadas por todo o país, porquanto 1.600 empresas congregam 50.000 empregados, ao passo que nove empresas produzem aproximadamente 165.000 empregos diretos e indiretos.

Assim, diante dos números apresentados, pode-se afirmar que o poder de barganha que possuem as empresas fabricantes de pneus novos é maior do que aquele das empresas reformadoras, o que pode influenciar a definição dos marcos regulatórios para o setor de fabricação de pneus novos e reformados.

\subsection{A questão ambiental}

Os pneus são, definitivamente, um desafio a ser enfrentado por qualquer programa de gerenciamento de resíduos sólidos urbanos.

\footnotetext{
${ }^{4} \mathrm{O}$ artigo $3^{\circ}$, XII, da Lei 12.305/2010 conceitua "logística reversa" como um "instrumento de desenvolvimento econômico e social caracterizado por um conjunto de ações, procedimentos e meios destinados a viabilizar a coleta e a restituição dos resíduos sólidos ao setor empresarial, para reaproveitamento, em seu ciclo ou em outros ciclos produtivos, ou outra destinação final ambientalmente adequada".

${ }^{5}$ Lei 12.305/2010, "Art. 33. São obrigados a estruturar e implementar sistemas de logística reversa, mediante retorno dos produtos após o uso pelo consumidor, de forma independente do serviço público de limpeza urbana e de manejo dos resíduos sólidos, os fabricantes, importadores, distribuidores e comerciantes de: [...] III - pneus;”.
} 
Isso porque, enquanto classificados pela Associação Brasileira de Normas Técnicas (ABNT) como resíduos inertes, a sua destinação teoricamente adequada revela-se, na verdade, um risco ambiental. ${ }^{6}$ Explica-se: o envio de pneus para aterros sanitários pode comprometer sensivelmente a vida útil destes, visto que o material em tela possui grandes dimensões, se comparado a outros resíduos de mesma natureza para ali enviados.

Além disso, possuem baixa compressibilidade, não são biodegradáveis e, quando entram em contato com alguns dos gases liberados pela decomposição de outros resíduos, podem inchar, pela absorção desses gases, e estourar, destruindo, assim, as camadas do aterro.

Quando dispostos em terrenos a céu aberto, por sua vez, os pneus acabam por servir como criadouro de mosquitos vetores de doenças, como a dengue e a malária, por exemplo, e, quando incinerados, liberam gases tóxicos e cancerígenos, bem como óleos, e estes, ao percolarem, podem contaminar os lençóis freáticos. Ainda nesse sentido, o trânsito de pneus usados poderia servir como meio de transporte para vetores de outras doenças ou até mesmo incrementar as estatísticas de doentes existentes no país, sendo que de todo o recurso orçamentário transferido aos Estados e municípios, 70\% é voltado para o combate e para a prevenção da dengue (MOROSINI, 2006), cuja incidência está diretamente relacionada ao descarte inadequado de pneus em terrenos a céu aberto.

Podem, ademais, contribuir para o assoreamento dos corpos d'água e entupimento de galerias fluviais, gerando, assim, mesmo que indiretamente, o transbordamento de rios e a ocorrência de enchentes nas grandes cidades.

As alternativas possíveis para a utilização de pneus inservíveis no país seriam de cinco tipos: utilização na pavimentação de estradas (asfalto-borracha); como fonte de energia para fornos de cimento, devido ao seu alto poder calorífico; coprocessamento na usina de xisto betuminoso, para a liberação de óleo e gás (Processo Petrosix ${ }^{\circledR}$ - unidade produtiva de Petróleo Brasileiro S.A.
- PETROBRAS); fabricação de artefatos de borracha e utilização no controle da erosão, absorção de impactos etc. (KWEITEL; SANCHEZ, 2007).

Não obstante todas as formas de destinação alternativas existentes, a implementação pode ser dispendiosa, pois requer tecnologia recente, de difícil acesso, além de intenso controle e monitoramento por parte do poder público, principalmente no que se refere aos níveis permitidos de emissão dos gases oriundos desses processos, e mesmo assim ainda resultar na geração de resíduos, muitas vezes perigosos.

Inexiste, atualmente, portanto, uma forma perfeita de destinação dos pneus inservíveis ou que gere minimamente impactos ambientais, afora as implicações no que atine ao uso de pneus para reforma.

Neste âmbito, alega-se que existiriam grandes dificuldades na coleta do material, pois que inexiste no país uma rede bem estruturada de concentração de pneus usados, acrescido do fato de que estes, quando originados do próprio país, estariam em condições praticamente impróprias para reforma, dado o péssimo estado de conservação das estradas brasileiras. Tais argumentos foram, inclusive, utilizados pelos defensores da liberação da importação dos pneus, o que se verá adiante (LIMA, 2008).

\subsection{A normatização brasileira}

O entendimento da evolução da normatização brasileira sobre resíduos, especialmente no que atine à importação destes, passa, necessariamente, pela discussão acerca da Convenção de Basileia sobre o Controle de Movimentos Transfronteiriços de Resíduos Perigosos e seu Depósito, que é um reflexo da política adotada correntemente pelos países ricos de transferir seus resíduos de difícil gestão para os países em desenvolvimento.

A Convenção é um documento que surgiu como fruto da Conferência de Plenipotenciários, ${ }^{7}$ ocorrida

\footnotetext{
${ }^{6}$ A expressão risco ambiental refere-se à acepção do Conselho Nacional do Meio Ambiente (CONAMA), órgão consultivo e deliberativo do Sistema Nacional do Meio Ambiente (SISNAMA), especialmente em sua Resolução n 305, de 12 de junho de 2002, na qual se considera risco como uma "medida de incerteza"; assim, por consequência, risco ambiental deve ser considerado como a medida de incerteza no conjunto de condições, leis, influência e interações de ordens física, química, biológica, social, cultural e urbanística, que permite, abriga e rege a vida em todas as suas formas.

${ }^{7}$ As Conferências resultam em Convenções, que são ratificadas em seguida pelos países que com estas concordem, não sendo vedada a adoção de acordos bilaterais ou multilaterais sobre a mesma questão, desde que não contrariem o disposto no documento geral.
} 
em Basileia, na Suíça, em 1989, e tem como objetivo primordial proteger a saúde humana e o ambiente contra os efeitos prejudiciais dos chamados "resíduos perigosos" - com base em sua origem, composição e características - e dos dois tipos de resíduos definidos como "outros resíduos", que são os resíduos domésticos e as cinzas produzidas em incineradores. Além disso, visa coibir o chamado "comércio de resíduos tóxicos", pelo qual países desenvolvidos utilizam os países pobres ou em desenvolvimento como depósitos de lixo, sendo este recebido algumas vezes em troca de dinheiro e, em outras, como imposição daqueles.

O Brasil ratificou a Convenção por meio do Decreto 875/1993, mas antes, em 1991, o Departamento de Operações de Comércio Exterior - DECEX, então vinculado ao Ministério da Fazenda, editou a Portaria no 8/1991, a qual, em seu artigo $27,{ }^{8}$ proibiu a importação de qualquer bem de consumo usado, aí se incluindo os pneus.

No ano seguinte, em 1992, o Instituto Brasileiro do Meio Ambiente e dos Recursos Naturais Renováveis (IBAMA) editou a Portaria $\mathrm{n}^{\circ} 138-\mathrm{N}$, a qual reforçou a aludida proibição, pela inserção dos pneus usados na categoria de resíduos sujeitos à importação proibida.

O Conselho Nacional do Meio Ambiente (CONAMA) editou várias resoluções para disciplinar a questão: a Resolução n 23/1996 definiu os resíduos perigosos e definiu o tratamento que lhes deveria ser outorgado, enquadrando os pneus usados na categoria de resíduos inertes, classe III, cuja importação seria proibida, pois, conforme fosse a disposição final dada, poderiam ser perigosos; a seguir, em 1999, foi publicada a Resolução ${ }^{\circ} 258 / 1999$, por meio da qual se instituiu a responsabilidade do produtor/importador pela destinação ambientalmente adequada para pneus inservíveis existentes no país na proporção, ${ }^{9}$ em 2007 , de quatro pneus produzidos ou importados novos para cinco pneus usados reciclados e, depois, para cada três pneus importados reformados de qualquer tipo, deveriam ser reciclados quatro pneus usados.

A inclusão dos pneus reformados nas Resoluções do CONAMA se deveu a uma necessidade de disciplinar a questão em termos ambientais e não somente como um problema de importação, subordinada ao Comércio Exterior, aliado ao fato de ter crescido muito o número de pneus reformados no país por força de liminares judiciais que concediam a permissão para a importação, incrementando, assim, o passivo ambiental brasileiro.

No mesmo ano, foi editado o Decreto 3.179/1999, que determinou penalidades por motivo de conduta e atividades lesivas ao meio ambiente, fruto da edição da Lei de Crimes Ambientais (Lei n ${ }^{\circ}$ 9.605/1998). Tal norma, porém, foi modificada pelo Decreto $n^{\circ} 3.919 / 2001$, que estabeleceu multa pecuniária, no valor de $\mathrm{R} \$ 400,00$, para cada pneu importado usado ou reformado encontrado no país.

A Resolução CONAMA n ${ }^{\circ}$ 301/2002 veio alterar alguns dispositivos da Resolução $n^{\circ} 258 / 1999$, para aumentar a responsabilidade dos importadores de pneus reformados quanto ao tratamento ambiental conferido aos seus resíduos, bem como para proibir a destinação dos resíduos de forma incorreta, como o descarte em rios, lagos, mar, riachos, terrenos baldios ou alagadiços, incineração a céu aberto, dentre outras. Novamente, a edição de tal medida surgiu em virtude do desrespeito à legislação, por parte de algumas empresas, bem como pelo aumento do número de pneus importados encontrados no país, em virtude das já aludidas liminares judiciais.

Pelo exposto, vê-se que o Brasil empreendeu tentativas no sentido de evitar o aumento do seu passivo ambiental, mesmo contrariamente a interesses comerciais de indústrias localizadas no país, pois que a proibição vetaria a entrada de um insumo mais barato e de melhor qualidade, ${ }^{10}$ incrementado pelo fato de inexistir no país

\footnotetext{
8 “Art. 27. Não será autorizada a importação de bens de consumo usados.” (BRASIL, 1991, s/p.).

9 "A partir de 2002, para cada 4 pneus produzidos ou importados (novos ou reformados) um pneu inservível deveria ser reciclado. A partir de 2003, a relação deveria ser de dois pneus produzidos ou importados (novos ou reformados) para um pneu inservível reciclado. Em 2004, a proporção foi de um pneu produzido ou importado novo para um pneu inservível reciclado. Em 2005, a proporção foi de que para cada 4 pneus produzidos ou importados novos, cinco pneus usados deveriam ser reciclados; e, para cada 3 pneus importados reformados de qualquer tipo deveriam ser reciclados 4 pneumáticos usados. As relações dos anos de 2005 a 2007 foram idênticas" (LAGARINHOS; TENÓRIO, 2009, p. 39).

${ }^{10}$ ESTADÃO, 2010. Impasse jurídico internacional mantém pneus usados no porto do Rio. Disponível em: <http://www.estadao.com.br/noticias/cidades,impasse-juridico-internacional-mantem-pneus-usados-no-porto-do-rio,543808,0.htm>. Acesso em: 10/12/2011.

FOLHA DE S. PAULO, 2003. Lula libera importação de pneus usados. Disponível em: <http://www1.folha.uol.com.br/fsp/cotidian/ff1302200329.htm>. Acesso em: $10 / 12 / 2011$.
} 
uma estrutura logística adequada para o recolhimento e disponibilização dos pneus usados, dentre outros fatores a seguir melhor desenvolvidos.

\section{O caso dos pneus levado à OMC}

Quando se vislumbra uma controvérsia levada ao conhecimento da $\mathrm{OMC}$, é preciso entender que a questão suscitada nasce muito antes do momento em que a parte Reclamante vai a juízo, no caso, ao OSC, para ver seu direito ao livre-comércio resguardado.

No caso em tela, não poderia ser diferente, pois que dezoito meses antes do pedido de celebração de consultas feito pelas Comunidades Europeias $(\mathrm{CE})^{11}$ ao Brasil, isto é, em janeiro de 2004, as medidas supostamente discriminatórias já eram discutidas no seio daquela comunidade de países europeus.

Tudo se iniciou, segundo Morosini (2006), a partir de uma notícia publicada no Jornal Oficial da União Europeia $^{12}$ por conta de uma reclamação (denúncia) originada a partir do Escritório Internacional Permanente das Associações de Vendedores de Pneus Reformados (no original, Bureau International Permanent des Associations de Vendeurs et Pneumatique), que representava os interesses de fabricantes de pneus reformados dentro da União Europeia.

Segundo o artigo $4^{\circ}$ do Regulamento $n^{\circ} 3286 / 1995$ do Conselho da União Europeia, qualquer empresa que se sentir prejudicada por um entrave comercial adotado por um país terceiro que contrarie algum acordo comercial multilateral vigente pode oferecer denúncia à Comissão Europeia para o Comércio, a qual adotará as medidas cabíveis com o fito de promover o livre comércio.

Segundo a notícia, algumas medidas brasileiras estariam impedindo a entrada dos pneus reformados originados da União Europeia (UE) e, além disso, o governo brasileiro teria determinado a imposição de multa pecuniária, no valor de $\mathrm{R} \$ 400,00$ (quatrocentos reais), para cada pneu reformado importado, comercializado, transportado, armazenado, guardado ou mantido em depósito em solo brasileiro.

Ainda informou a notícia que a União Europeia estaria enfrentando prejuízos econômicos significativos em função das medidas restritivas brasileiras, vez que aquele bloco de países exportava anualmente, à época, dois milhões de unidades do produto, o que representava vinte e cinco por cento do mercado nacional brasileiro. Os principais afetados eram os produtores do Reino Unido, da Itália e da Espanha, que detinham a maior parte das exportações para o Brasil.

A publicação da notícia ensejou, assim, a abertura de um procedimento de investigação interno da UE, que foi conclusivo no sentido de que realmente o Brasil teria adotado medidas restritivas não justificáveis por razões sanitárias e/ou ambientais e, por isso, a UE iniciou negociações diplomáticas com aquele país para que revogasse as normativas restritivas.

\subsection{A tramitação jurídica do caso no âmbito internacional: linha do tempo de julho de 2005 a setembro de 2009}

Como as negociações não chegaram a bom termo, em 20 de junho de 2005 as Comunidades Europeias solicitaram consultas em face do Brasil no âmbito da OMC para solucionar a controvérsia.

A partir desse momento, o caso teve o seguinte deslinde:

- $\quad$ em 4 de julho de 2005, a Argentina requereu participação nas consultas como terceira parte, por se sentir afetada pela questão suscitada;

- em 20 de julho de 2005, o Brasil aceitou a inserção da Argentina como terceira parte e, neste mesmo dia, as consultas foram celebradas em Genebra, na Suíça;

\footnotetext{
${ }^{11} \mathrm{O}$ termo Comunidades Europeias é utilizado neste trabalho no plural porque é assim que os documentos da OMC se referem à União Europeia, posto que esta resulta da fusão da Comunidade Europeia do Carvão e do Aço (CECA), da Comunidade Econômica Europeia (CEE) e da Euratom (Comunidade Europeia da Energia Atômica), por força do tratado de fusão dos executivos das três Comunidades, assinado em 1967.

12 JORNAL OFICIAL DA UNIÃO EUROPEIA, 2004. Aviso de início de um processo de exame respeitante a entraves ao comércio, na acepção do disposto no Regulamento (CE) $n^{\circ}$ 3286/94 do Conselho, que consistem em práticas comerciais mantidas pelo Brasil em relação à importação de pneumáticos recauchutados. Disponível em: <http://eur-lex.europa.eu/LexUriServ/LexUriServ.do?uri=OJ:C:2004:003:0002:0003:PT:PDF>. Acesso em: 09/12/2011.
} 
- em 17 de novembro de 2005, as Comunidades Europeias solicitaram o estabelecimento de um Painel (ou Grupo Especial); ${ }^{13}$

- em 20 de janeiro de 2006, foi estabelecido o Painel;

- em 16 de março de 2006, foram estabelecidos os componentes do Painel, pois Brasil e CE não chegaram a um acordo sobre os membros nos vinte dias seguintes ao estabelecimento do Painel;

- em 21 de dezembro de 2006, o Painel comunicou que seus trabalhos não iriam terminar no prazo previsto inicialmente;

- de 5 a 7 de julho de 2006 e em 4 de setembro do mesmo ano, o Painel se reuniu com as partes; em 6 de julho de 2006 o Painel se reuniu com os Terceiros interessados;

- em 12 de junho de 2007, o Painel apresentou seu relatório;

- em 4 de setembro de 2007, as CE interpuseram apelação;

- $\quad$ em 3 de dezembro de 2007, o OA apresentou seu relatório;

- em 17 de dezembro de 2007, o OSC adotou a decisão do $\mathrm{OA}$;

- em 26 de junho de 2008, foi instituída a arbitragem para decidir sobre o tempo que o Brasil teria para implementar as decisões do OSC;

- $\quad$ em 17 de dezembro de 2008, foi concedido prazo final ao Brasil para implementação das decisões do OSC;

- em 15 de setembro de 2009, o Brasil informou a adoção das medidas recomendadas pelo OSC.

Os dados apresentados na linha do tempo evidenciam que houve resistência de ambas as partes em solucionar o conflito, posto que estavam em discussão altos interesses econômicos e ambientais. Isso porque a partir de 2006 os europeus estariam obrigados a retirar dos veículos em fim de vida os pneus e não podiam enviá-los, sob qualquer forma, até mesmo triturados ou cortados, para aterros sanitários, de forma que se tornara imprescindível encontrar uma forma de transferir para terceiros esse passivo ambiental, sem perder o valor econômico por ele proporcionado.

$\mathrm{Na}$ fase de consultas, o Brasil respondeu às questões suscitadas pelas $\mathrm{CE}$, as quais versaram basicamente sobre as mesmas apresentadas quando da solicitação da instauração do Painel, porém, as respostas formuladas não foram satisfatórias às $\mathrm{CE}$ e, dessa forma, o caso teve continuidade com a abertura do Painel. O Painel deu ganho de causa quase que total às $C E$, porém, como a interpretação de uma questão não foi condizente com o interesse das CE, estas recorreram ao Órgão de Apelação, que reverteu quase todos os entendimentos do Painel e, ao final, o Brasil saiu muito beneficiado com o julgamento. Para se ter uma ideia, em comparação com o primeiro contencioso em que o Brasil se envolveu, o caso da gasolina americana, ${ }^{14}$ este contencioso acerca dos pneus teve quase o dobro da duração, ${ }^{15}$ demonstrando que houve uma acirrada negociação. Além disso, participaram vários países como terceiros interessados, ${ }^{16}$ bem como algumas organizações internacionais, que manifestaram apoio à causa brasileira na forma de apresentação de relatórios ao Painel na condição de amicus curiae. ${ }^{17}$

Ainda, é importante observar que durante o prazo concedido ao Brasil para implementação das decisões do Órgão de Apelação, já depois de finalizado o caso, aconteceu o incidente em que foram exportados para o Brasil 89 contêineres de lixo originados da Grã-Bretanha contendo baterias, seringas, preservativos, restos de comida e fraldas descartáveis, evidenciando-se, assim, que esta prática de enviar resíduos para o Brasil ocorria de fato.

\footnotetext{
${ }^{13}$ Painel e Grupo Especial são expressões sinônimas.

${ }^{14}$ Caso DS2 - "Standards for Reformulated and Conventional Gasoline", que, numa tradução livre, pode ser intitulado "Padrões para a gasolina reformulada e convencional", em que foram partes principais o Brasil e os Estados Unidos, sendo este o Reclamado e aquele o Reclamante.

${ }^{15}$ O caso da gasolina teve início em janeiro de 1995 e foi concluído em abril de 1996, sendo que os Estados Unidos anunciaram a implementação das medidas requisitadas pelo Painel em setembro de 1997, contabilizando-se, assim, no total, 32 meses; o caso dos pneus, por outro lado, iniciou em junho de 2005 e foi concluído em agosto de 2008, tendo o Brasil comunicado a implementação das medidas requisitadas em setembro de 2009 , totalizando 51 meses.

${ }^{16}$ Argentina, Austrália, China, Coreia do Sul, Cuba, Estados Unidos. Guatemala, Japão, México, Paraguai, Tailândia, Taipé Chinês.

${ }^{17}$ Amicus curiae é uma expressão latina que quer dizer "amigo da corte" e se refere, neste trabalho, à intervenção de entidades representativas na causa em discussão na OMC. No caso em tela, entidades como a Humane Society International e a Associação de Combate aos Poluentes apresentaram seus relatórios ao Painel como forma de apoio ao Brasil.
} 


\subsection{As medidas impugnadas}

As Comunidades Europeias solicitaram a instauração de um Painel porque, como se viu anteriormente, as consultas celebradas não lograram êxito.

Quando dos pedidos, tanto o referente às consultas quanto aquele ao Painel, as CE argumentaram que o Brasil implementou medidas:

1. de proibição de importação de pneus reformados, em particular em virtude da Portaria n. 17/2003, da Secretaria de Comércio Exterior (SECEX) do Ministério do Desenvolvimento, Indústria e Comércio Exterior (MDIC);

2. de adoção de um conjunto de medidas ${ }^{18}$ pelo qual se proíbe a importação de pneus reformados, que às vezes se aplicam a importações de pneus reformados, apesar do fato de que estes não são pneus usados;

3. de imposição, por meio do Decreto n. 3.919/ 2001, de uma multa de quatrocentos reais para cada unidade de pneu recauchutado importado, comercializado, transportado, armazenado, conservado ou mantido em depósito;

4. de isenção, tanto da multa supra como a da proibição de importação de pneus reformados aos países integrantes do Mercado Comum do Sul (MERCOSUL).

Em resumo, o Brasil adotou medidas legais para proibir a importação de pneus reformados, usados ou não, e aplicar uma multa no valor de quatrocentos reais para cada unidade de pneu reformado importado encontrado (comercializado, transportado, armazenado, conservado ou mantido em depósito) no país, sendo isentos de cumprir essas determinações todos os países do MERCOSUL, em função daquilo que foi decidido no Tribunal Arbitral Ad Hoc deste bloco de integração em janeiro de 2002. ${ }^{19}$

Para cada uma das medidas adotadas pelo Brasil, as $\mathrm{CE}$ argumentaram que estariam sendo descumpridos determinados dispositivos do GATT, quais sejam, respectivamente:

1. o Brasil atuou de forma incompatível com o parágrafo $1^{\circ}$ do artigo XI do GATT ao impor e manter uma proibição e restrição distinta de um direito aduaneiro, tributo ou outra carga à importação e outras medidas;

2. o Brasil atuou de forma incompatível com o parágrafo $1^{\circ}$ do artigo XI e/ou com o parágrafo $4^{\circ}$ do artigo III do GATT de 1994 ao impor e manter uma restrição distinta de um direito aduaneiro, tributo ou outra carga à importação de um produto do território de outro membro, aplicada mediante uma multa imposta à importação de pneumáticos reformados sob a quantia de quatrocentos reais por unidade;

3. o Brasil atuou de forma incompatível com o parágrafo $4^{\circ}$ do artigo III e/ou com o parágrafo $1^{\circ}$ do artigo XI do GATT de 1994 ao impor uma multa de quatrocentos reais por cada pneumático que é vendido, transportado, armazenado, conservado ou mantido em depósito ou em lojas; em consequência, o Brasil não concedeu aos produtos oriundos das Comunidades Europeias um tratamento não menos favorável do que o concedido aos produtos similares de origem nacional, no que concerne a leis, regulamentos e prescrições que afetam a venda, a oferta para venda, a compra, o transporte, a distribuição e o uso desses produtos no mercado interno;

4. o Brasil atuou de forma incompatível com o parágrafo $1^{\circ}$ do artigo I do GATT de 1994 ao eliminar a proibição de importação e as sanções financeiras antes mencionadas para os produtos oriundos do MERCOSUL, mantendo ao mesmo tempo essas medidas em desfavor dos produtos importados das CE; em consequência, o Brasil não tem outorgado uma vantagem concedida aos produtos originários de

\footnotetext{
${ }^{18}$ Portaria SECEX no 8/1991; Portaria SECEX no 18/1992; Portaria IBAMA no 138-N/1992; Portaria MICT no 370/1994; Portaria Interministerial no 3/1995 do MICT e do Ministério da Economia; Resolução n 23/1996 e Resolução n 235/1998, do CONAMA.

${ }^{19} \mathrm{O}$ Tribunal Arbitral $A d$ Hoc do MERCOSUL foi constituído para entender a controvérsia apresentada pela República Oriental do Uruguai à República Federativa do Brasil sobre "Proibição de Importação de Pneumáticos Remoldados (Remolded) Procedentes de Uruguai" e apresentou seu relatório em janeiro de 2002.
} 
outros países, com respeito aos regulamentos e formalidades relativos às importações, e com respeito às questões a que se refere o parágrafo $4^{\circ}$ do artigo III, imediata e incondicionalmente aos produtos similares originários do território das Comunidades Europeias;

5. ao aplicar a proibição de importação de pneumáticos reformados antes mencionada, assim como a sanção financeira a cada unidade de pneumáticos reformados importados das Comunidades Europeias, mas não aos importados de outros países do MERCOSUL, o Brasil atua de forma incompatível com o parágrafo $1^{\circ}$ do artigo XIII do GATT de 1994, porque impõe proibição e restrição à importação de um produto originário do território de outro membro, embora não se imponha uma proibição ou restrição semelhante à importação de produto similar originário de qualquer terceiro país.

Em outras palavras, as $\mathrm{CE}$ alegaram que o Brasil descumpriu o disposto nos artigos I: $1^{\circ}$, III: $4^{\circ}, \mathrm{XI}: 1^{\circ}$, XIII:1 ${ }^{\circ}$ do GATT 1994.

$\mathrm{O}$ artigo I: $1^{\circ}$ refere-se à Nação Mais Favorecida; o III: $4^{\circ}$, ao Tratamento Nacional no tocante à Tributação e Regulamentação Internas; o XI: $1^{\circ}$ refere-se à Eliminação Geral de Restrições Quantitativas; o XIII:1 ${ }^{\circ}$, por sua vez, à Aplicação Não Discriminatória das Restrições Quantitativas.

A cláusula da Nação Mais Favorecida teria sido, então, supostamente descumprida pelo Brasil na medida em que este concedeu uma vantagem (qualquer que seja, relacionada às importações e exportações, de acordo com o próprio GATT 1994) a um produto originário de um bloco econômico (o MERCOSUL), mas não estendeu esta condição vantajosa aos produtos similares originários de outros países, especialmente das Comunidades Europeias. A vantagem seria permitir a importação de pneus recauchutados de qualquer país integrante do MERCOSUL e não permitir aquela oriunda das CE, além de não impor a multa de quatrocentos reais a esses produtos.

O dispositivo do Tratamento Nacional no tocante à Tributação e Regulamentação Internas aduz que não poderiam ser taxados produtos importados de modo a favorecer a produção nacional. No caso em tela, a imposição da multa de quatrocentos reais por unidade de pneu recauchutado importado, a despeito da não cobrança aos pneus recauchutados produzidos no país, seria uma infração a esse dispositivo.

A Eliminação Geral de Restrições Quantitativas teria sido contrariada na medida em que instituiu, para a importação de produtos originários das $\mathrm{CE}$, uma restrição que não constituía direito alfandegário, imposto ou taxa aduaneira, a qual foi efetuada por meio de negação de licença de importação, por força das portarias SECEX 14/2004 e DECEX 8/1991.

A Aplicação Não Discriminatória das Restrições Quantitativas teria sido infringida na medida em que foi aplicada uma restrição pelo Brasil somente à importação de pneus recauchutados originários das $\mathrm{CE}$, sem que produto similar de outros países tenha sido restringido; no caso, os pneus recauchutados de qualquer país do MERCOSUL poderiam entrar livremente no Brasil.

Também serviu como fundamento ao pedido das CE o fato de tribunais brasileiros estarem concedendo liminares a empresas para que importassem pneus reformados, contrariamente ao que preconizava a legislação pátria, bem como o de existir em alguns Estados da Federação legislações autorizativas da importação.

O Brasil respondeu juridicamente a essas acusações nos seguintes termos: que a proibição à importação se justifica pela alínea (b) do Artigo XX do GATT 1994, vez que se trata de uma medida necessária à proteção da vida e da saúde humana, animal e vegetal e do meio ambiente; além disso, as multas pecuniárias aplicadas a quem importa, comercializa, transporta, armazena, guarda ou mantém em depósito pneumático usado ou recauchutado são justificáveis por conta das alíneas (b) e (d) do Artigo XX do GATT 1994; por fim, que os artigos XXIV e a alínea (d) do Artigo XX autorizam o Brasil a eximir os outros países do MERCOSUL à proibição da importação e das multas pecuniárias.

Na matéria de fato, o Brasil alegou que a importação de pneus reformados contribuía para a geração de uma grande quantidade de resíduos no país, visto que esses pneus não poderiam mais sofrer processo de reforma.

Tal geração excedente provocava, além do problema da gestão de resíduos, ameaças à saúde pública e ao meio ambiente, visto que os pneus são, por sua 
estrutura física, naturalmente propícios ao acúmulo de água de chuva, o que poderia servir como foco de vários mosquitos transmissores de doenças, como a malária e a dengue, dentre outras.

A destinação desse material para os aterros sanitários também poderia comprometer o correto funcionamento destes, pois que ocupam grandes espaços e não são biodegradáveis. Além disso, a incineração de pneus produz gases cancerígenos, claramente maléficos à saúde das pessoas, dos animais e dos vegetais, nos termos da alínea (b) do Artigo XX.

A medida proibitiva seria, segundo o Brasil, a única medida capaz de impedir essa geração desenfreada de resíduos, bem como de promover a reutilização dos pneus usados existentes no país pelas próprias indústrias aqui instaladas. Tal ciclo acabaria por diminuir o montante de pneus usados disponíveis no país e, assim, o Brasil finalmente poderia resolver o problema da gestão desses resíduos.

Com relação à existência de legislação estadual contrária aos provimentos federais, o Brasil aduziu que tais normatizações não teriam o condão de regulamentar o comércio internacional, por serem materialmente inconstitucionais, e que o Painel não deveria, portanto, se reportar a elas.

\subsection{A decisão do Painel e o recurso das $C E$}

Em seu Relatório, o Painel concluiu que:

1. as portarias SECEX 14/2004 e DECEX 8/1991 são incompatíveis com parágrafo $1^{\circ}$ do Artigo XI do GATT de 1994, porquanto proíbem a expedição de licenças de importação de pneus reformados e não estão justificadas pela alínea "b" do Artigo XX do GATT de 1994;

2. a Resolução 23/1996 do CONAMA não é incompatível com o parágrafo $1^{\circ}$ do Artigo XI;

3. as multas impostas pelo Brasil sobre a importação, comercialização, transporte, armazenamento, conservação ou manutenção em depósito de pneus, por força do Decreto 3.919/2001, são incompatíveis com o parágrafo $1^{\circ}$ do Artigo XI do GATT de 1994, porquanto impõem condições limitativas em relação à importação de pneus reformados e não estão justificadas pelas alíneas " $b$ " e "d" do Artigo XX do GATT de 1994;

4. as medidas relativas aos pneus reformados mantidas pelo Estado do Rio Grande do Sul por força da Lei 12.114/2004, em sua forma modificada pela Lei $12.381 / 2005$, são incompatíveis com o parágrafo $4^{\circ}$ do Artigo III do GATT de 1994, porquanto outorgam aos pneumáticos reformados importados um trato menos favorável do que o concedido aos produtos nacionais similares e não se justificam em função da alínea "b" do Artigo XX do GATT de 1994;

5. as isenções ao MERCOSUL estabelecidas pelo Brasil são incompatíveis com o parágrafo $1^{\circ}$ do Artigo XIII e com o parágrafo $1^{\circ}$ do Artigo I do GATT de 1994 (decisão feita com base na aplicação do princípio da economia processual), mas não estão em desconformidade com a alínea "b" do Artigo XX.

O Painel concluiu, então, que as medidas acima enumeradas, enquanto incompatíveis com o GATT de 1994, com base no parágrafo $8^{\circ}$ do Artigo III do ESC, têm anulado ou comprometido vantagens resultantes deste acordo para as $\mathrm{CE}$ e, portanto, o Brasil deve se adequar ao estabelecido por aquele órgão em seu Relatório.

Não obstante, apesar da vitória em quase todos os aspectos pleiteados, as CE mesmo assim interpuseram apelação contra a decisão do Painel em função dos seguintes argumentos (os pontos mais importantes estão grifados):

1) a constatação do Grupo Especial de que a proibição das importações de pneumáticos recauchutados era "necessária" no sentido da alínea "b" do Artigo XX do GATT de 1994 é imprópria porque:

- ao avaliar a contribuição da medida à proteção à saúde e à vida das pessoas, dos animais e à preservação dos vegetais, o Painel simplesmente avalia se a proibição é suscetível de fazer uma possível contribuição aos objetivos declarados pela medida restritiva. Ademais, ao alegar, em sua conclusão, sobre a possível contribuição da proibição, o Painel tampouco 
fez uma avaliação objetiva dos fatos que lhes foram submetidos, como exige o Artigo 11 do ESC, e efetivamente transferiu o ônus da prova para as CE, o que deveria ser do Brasil, em tese, pois que este país é quem utiliza o argumento da proteção ambiental como linha de defesa;

- ao avaliar a existência de medidas alternativas razoavelmente disponíveis, o Painel exclui erroneamente algumas das alternativas propostas pelas CE, baseando-se no fato de que essas alternativas estão relacionadas com a maneira pela qual a proibição das importações se aplica na prática, que nem sempre estão facilmente disponíveis, que não evitam os resíduos de pneus derivados especificamente dos pneus recauchutados importados, os quais já existem no Brasil, ou que individualmente só podem eliminar um número reduzido de resíduos de pneus. Ademais, o Painel ignorou fatos e argumentos importantes apresentados pelas Comunidades Europeias e se referiu de maneira distorcida às provas apresentadas pelas partes, transferindo o ônus da prova para as $\mathrm{CE}$;

- por todos os motivos acima elencados, a constatação contida no item (1) contraria a correta interpretação do preâmbulo do Artigo $\mathrm{XX}$;

- além disso, e por fim, o Painel interpretou erroneamente o conteúdo jurídico da alínea "b" do Artigo XX do GATT de 1994 ao não sopesar e confrontar os fatores e elementos pertinentes (o objetivo perseguido, as restrições ao comércio derivadas da medida, a contribuição e as alternativas);

2. a constatação do Painel de que a isenção da proibição das importações e outras medidas impugnadas aos países do MERCOSUL não constitui uma discriminação arbitrária nem injustificável é incompatível com o preâmbulo do Artigo XX do GATT de 1994;

3) a constatação do Grupo Especial de que as importações de pneumáticos usados não constituem uma discriminação arbitrária e que constituem uma discriminação injustificada unicamente na medida em que comprometem significativamente os objetivos da proibição é incompatível com o preâmbulo do Artigo XX do GATT de 1994;

4) a constatação do Grupo Especial de que a isenção ao MERCOSUL não constitui uma restrição encoberta ao comércio internacional e que as importações de pneumáticos usados constituem uma restrição encoberta unicamente na medida em comprometem significativamente os objetivos da proibição;

5) a decisão do Painel de aplicar o princípio da economia processual com respeito às alegações formuladas pelas Comunidades Europeias ao amparo do parágrafo $1^{\circ}$ do Artigo XIII e do parágrafo $1^{\circ}$ do Artigo I do GATT. Posto que o Painel constatou que a isenção ao MERCOSUL não é incompatível com o preâmbulo do Artigo XX do GATT, para assegurar uma solução positiva da controvérsia, como exigem os parágrafos $3^{\circ}, 4^{\circ} \mathrm{e}$ $7^{\circ}$ do Artigo $3^{\circ}$ e do Artigo 11 do ESC, seria necessária uma constatação separada sobre a compatibilidade desta isenção com o parágrafo $1^{\circ}$ do Artigo XIII e com o parágrafo $1^{\circ}$ do Artigo I do GATT de 1994. Para tanto, as CE solicitam ao Órgão de Apelação que constate que a isenção ao MERCOSULé incompatível com o parágrafo $1^{\circ}$ do Artigo XIII e com o parágrafo $1^{\circ}$ do Artigo I do GATT de 1994 e não está justificado pelo Artigo XXIV nem pela alínea "d" do Artigo XX do GATT de 1994.

\subsection{As implicações econômicas e o destaque ao meio ambiente no caso}

O caso "Brasil - Medidas que afetam a importação de pneus recauchutados" possui vários elementos não jurídicos que merecem discussões mais aprofundadas, as quais serão desenvolvidas a seguir.

Na realidade, o deslinde jurídico foi complexo e demorado, de 2005 a 2009, mas o que ensejou essa falta de 
celeridade na conclusão do caso foi exatamente a riqueza do embate travado entre as Comunidades Europeias e o Brasil, o qual teve, inclusive, a participação de vários representantes de Organizações Não Governamentais, na condição de amicus curiae.

O primeiro elemento teria relação com o fato de a OMC não poder intervir quanto ao nível de proteção ambiental que determinado país quer estabelecer dentro de seus limites territoriais, pois que não está no escopo daquele fórum mundial essa competência. Ao contrário, o seu objetivo é promover o livre-comércio e, se forem colocados em confronto o direito ao livre-comércio e o direito ao meio ambiente, este prevalecerá, sem se discutir a pertinência da questão ambiental, mas sim se esta realmente é o desiderato da medida, por força da aplicação do Artigo XX ${ }^{20}$ do GATT de 1994.

Ainda, é pacífico na OMC o fato de que os países têm ampla liberdade para manter o nível de proteção ambiental que desejarem, estipulando arbitrariamente o nível de prevenção a riscos que lhes convier.

Ademais, é cediço que a Organização Mundial do Comércio não é um órgão ambiental internacional e que, portanto, não é no seu bojo que devem ser desenvolvidas discussões em relação a essa temática, não obstante o fato de a proteção ambiental constar do seu Acordo Constitutivo. ${ }^{21}$

A segunda questão relevante para o caso são as contínuas tentativas empreendidas pelos países desenvolvidos no sentido de exportar, para os países em desenvolvimento, o seu volume de resíduos que não pode ser enviado, por força de suas rígidas leis ambientais, para os seus próprios aterros sanitários, tendo, portanto, nesta prática, uma saída rápida e econômica para o não enfrentamento do problema da destinação dos resíduos produzidos.
Esses países, portanto, praticam uma espécie diferenciada de dumping ecológico, vez que se aproveitam da fragilidade das legislações ambientais dos países em desenvolvimento, ou mesmo desrespeitam os acordos internacionais assinados por estes, para enviar o lixo sob a forma de "bens de consumo", insumos e até mesmo como resíduo propriamente dito, como aconteceu em $2009^{22}$ com o Reino Unido, que enviou quase duas toneladas de lixo para o Brasil.

Assim, a transferência de resíduos indesejáveis para países subdesenvolvidos ou em desenvolvimento é uma prática ilegal que é reiteradamente aplicada, pelos países ditos desenvolvidos, como saída para a minimização dos seus problemas de gestão desse passivo ambiental.

A preocupação das Comunidades Europeias com a gestão dos resíduos teve início a partir de 1989, quando, por ocasião da Convenção de Basileia, passaram a investigar a questão e encontraram problemas em 20 categorias de resíduos (MINISTÉRIO DO MEIO AMBIENTE, s/data).

Não obstante o fato de até hoje não possuírem qualquer legislação específica direcionada para os pneus, dez anos depois - 1999 - começaram a ser implementadas diretivas ${ }^{23}$ sobre a questão dos resíduos em geral, as quais contemplavam os pneus, como já mencionado em parágrafos anteriores - a Diretiva sobre Aterros (1999/31/CE); a Diretiva sobre Veículos no Fim de sua Vida Útil (2000/53/CE) e a Diretiva sobre Incineração de Resíduos (2000/76/CE).

A Diretiva sobre Aterros tinha como objetivo prevenir ou reduzir os efeitos ambientais negativos sobre o ambiente como resultado da disposição de resíduos em aterro; com a Diretiva sobre Veículos no Fim de sua Vida Útil, a União Europeia pretendia limitar a produção

\footnotetext{
${ }^{20} \mathrm{O}$ Artigo XX, como já mencionado anteriormente, trata das exceções gerais e contempla hipóteses nas quais as medidas restritivas impostas pelos países são permitidas. 21 "Reconhecendo que as suas relações na esfera da atividade comercial e econômica devem objetivar a elevação dos níveis de vida, o pleno emprego e um volume considerável e em constante elevação de receitas reais e demanda efetiva, o aumento da produção e do comércio de bens e de serviços, permitindo ao mesmo tempo a utilização ótima dos recursos mundiais em conformidade com o objetivo de um desenvolvimento sustentável e buscando proteger e preservar o meio ambiente e incrementar os meios para fazê-lo, de maneira compatível com suas respectivas necessidades e interesses segundo os diferentes níveis de desenvolvimento econômico..." (MINISTÉRIO DO DESENVOLVIMENTO, INDÚSTRIA E COMÉRCIO EXTERIOR, s/ data, s/ p.).

${ }^{22}$ Disponível em: <http://noticias.terra.com.br/brasil/noticias/0,,OI3880989-EI306,00-Lixo+enviado+ao+Brasil+sera+devolvido+GraBretanha+apura+caso.html>. Acesso em: 20/12/2011.

${ }^{23}$ As Diretivas não são leis em sentido estrito, pois que requerem uma transposição para o direito nacional de cada país membro, deixando em aberto a escolha das formas e dos meios para a sua concretização, dispondo os países, para isso, de um prazo para colocá-las em prática.
} 
de resíduos provenientes dos veículos e intensificar a reutilização, a reciclagem e outras formas de valorização dos veículos em fim de vida e dos seus componentes. Com o fito de alcançar esse duplo objetivo, fixou novos requisitos para os fabricantes europeus, nomeadamente a obrigação de conceber veículos fáceis de reciclar. A Diretiva sobre Incineração de Resíduos, por sua vez, possuía o fito de estabelecer medidas destinadas a prevenir ou reduzir a poluição do ar, da água e do solo causada pela incineração, bem como pela coincineração de resíduos, assim como os riscos para a saúde humana daí resultantes. As medidas impunham, assim, a obtenção de uma licença para as instalações de incineração ou de coincineração e limites para a emissão para a atmosfera de certas substâncias poluentes e para a sua descarga na água.

Em termos práticos, os europeus, a partir de 2006, estavam proibidos de dispor em aterros pneus triturados ou cortados e os sucateiros estavam obrigados a retirar, dos veículos em fim de vida, os pneus.

Dessa forma, as Comunidades Europeias passaram a adotar a exportação de pneus usados e reformados como medida estratégica de gestão de resíduos e foi assim que o Brasil, país em desenvolvimento com a maior frota de veículos de passeio do mundo, se tornou o destino preferido para essa transferência.

O problema reside justamente em que o Brasil já possuía, a essa época, um enorme passivo ambiental de pneus no país, resultante tanto da indústria de liminares judiciais, concedidas mesmo durante a vigência das diversas portarias proibitivas de importação, quanto da violação direta a essas regras por parte das empresas instaladas no país. Além disso, o Brasil conseguiu demonstrar que a importação de pneus reformados contribuiria para incrementar ainda mais esse número, visto que, após o uso, não servem mais para um novo processo de reforma, mas tão somente devem ser encaminhados para tratamento com fins de reciclagem ou destinados para aterros sanitários.

Além disso, como terceira observação, em 2001 o Brasil alterou o Decreto 3.179/1999 para conceder isenção à proibição para os países do MERCOSUL, por força de uma decisão do seu Tribunal Arbitral ad hoc, na qual saiu perdedor.
O problema é que a fundamentação brasileira desenvolvida junto àquele Tribunal Arbitral se baseou em argumentos econômicos, e não ambientais. Se os motivos ambientais eram tão prementes para o Brasil, por que este país teria desperdiçado a excelente chance de desfiar seus reais motivos em um fórum internacional?

A partir de 1991, bastante influenciado pelo aumento do número de pneus reformados no país, que neste ingressaram por força de liminares judiciais que concediam a permissão para a importação, o Brasil passou a normatizar a questão por meio de órgãos ambientais. Nesse sentido, teria sido vantajoso ao país focar a discussão, no contencioso do MERCOSUL, em termos ambientais, e não somente econômicos.

Além disso, em quarta análise, o Brasil justificou a isenção da medida concedida aos países do MERCOSUL pelo fato de ter sido compelido a cumprir uma obrigação por conta de uma decisão do Tribunal Arbitral e não em decorrência da exceção contida no Artigo XX do GATT.

Como decorrência desta última análise, a quinta reflexão se dá em torno dos motivos que justificaram o entendimento dos membros do Painel de que a medida de isenção concedida pelo Brasil não se enquadrava como discriminação arbitrária ou injustificada em face do volume de pneus importado, que, segundo eles, não seria capaz de comprometer o objetivo da medida restritiva. Em outras palavras: como o fluxo de pneus importados dos países do MERCOSUL era irrisório, ou insignificante, diante daquele das Comunidades Europeias, então tal medida não comprometeria o objetivo da medida proibitiva brasileira, qual seja, a proteção da vida e da saúde mediante a diminuição do passivo ambiental ocasionado pelo descarte inadequado de pneus usados/inservíveis.

Com isso, não se verifica uma continuidade na utilização de determinados padrões jurídicos para análise dos casos, o que traz realmente sensação de insegurança jurídica quando da análise dos argumentos apresentados pelas partes, visto que interpretações divergentes poderiam ser utilizadas para situações semelhantes, contrariando a lógica utilizada no OSC, em que, regra geral, uma interpretação dada em determinado Painel é utilizada como parâmetro para as seguintes.

Assim, o Painel não considerou a isenção incompatível com o caput do Artigo XX do GATT, o que motivou o recurso das CE. A isenção passou no "teste 
de adequação e necessidade", que é feito sempre quando se vai analisar o cabimento de medidas restritivas com justificativa ambiental.

Não obstante a possível sensação de insegurança jurídica que a recepção de argumentos não preponderantemente jurídicos possa trazer para o OSC, é possível vislumbrar, por meio desse caso, que há uma tendência de graduação do tratamento conferido aos países conforme sua necessidade de tratamento especial, e não somente a verificação da procedência do direito pleiteado em juízo.

Em sexto lugar, ficou evidente o posicionamento diferenciado das três esferas de Poder brasileiras: o Executivo editou provimentos para tornar concreto o direito ao meio ambiente ecologicamente equilibrado preconizado na Carta Magna; o Legislativo não se posicionou a esse respeito, no âmbito federal, e o Judiciário, em contradição a preceitos constitucionais da maior magnitude, principalmente se se entender o direito ao meio ambiente e o direito à saúde como corolários do direito à vida, concedeu inúmeras liminares a empresas reformadoras de pneus, sob o argumento, na maioria das vezes, de que não havia lei regulando a matéria. Assim, a atuação individualizada de cada Poder, apesar de ser um movimento natural do sistema tripartido, pode ter repercutido sobre a questão.

O fato é que a decisão do Painel havia sido, em parte, benéfica à política ambiental brasileira - $\underline{\text { sétima }}$ observação, pois as decisões dos juízes, bem como a Lei $12.381 / 2005$, foram consideradas injustificáveis e, se não fosse a ganância jurídica das CE para que a isenção ao MERCOSUL fosse considerada incompatível com o caput do Artigo XX, o Brasil não teria ganho a questão em sede de apelação, uma vez que as Comunidades Europeias teriam se conformado com a decisão do Painel, que lhe foi totalmente benéfica.

Não obstante se falar em ganância jurídica, a irresignação das CE tem sua razão de ser. Isso porque o conteúdo das decisões do Painel serve como precedente para decisões futuras, e não somente as suas conclusões finais, e, provavelmente, a interpretação jurídica do caput do Artigo XX dada no caso em tela poderia ser novamente utilizada, fato que motivou as $\mathrm{CE}$ a interporem o recurso.

Quando da Apelação, o entendimento foi revisto, de modo que a isenção não foi mais considerada justifi- cável e o Brasil teve de cassar aquela medida favorável ao MERCOSUL.

Não obstante, ao final o Brasil saiu vitorioso, pois, embora tenha considerado a isenção injusta, o Órgão de Apelação reverteu o entendimento do Painel, de forma a entender, sim, as medidas proibitivas gerais, isto é, aquelas que proibiam a importação de pneus usados ou reformados e atribuía multa para aquelas empresas que desobedecessem a esta determinação, adequadas à hipótese da alínea "b", e necessárias, no sentido do caput do Artigo XX.

\section{Considerações finais}

Por todo o exposto, vê-se que a Guerra dos Pneus não foi simplesmente um caso jurídico. Longe disso, representou um embate de forças violentas, como o poder representado pelas Comunidades Europeias, historicamente em posição hegemônica, versus aquele representado pelo Brasil, reconhecidamente o líder dos países emergentes, ou em desenvolvimento.

No Brasil, enquanto a competência era do Ministério da Fazenda, tentou-se tratar a questão da importação de pneus recauchutados como meramente econômica; a partir de 1992 é que o tema passou a ser disciplinado como uma questão ambiental e o IBAMA, órgão integrante da estrutura do MMA, editou uma portaria (Portaria $138-\mathrm{N})$ que incluiu os pneus usados na lista dos bens cuja importação estaria vedada. A partir desse momento, foram editadas resoluções pelo CONAMA que, pouco a pouco, foram normatizando a questão dos resíduos de pneus no país, classificando-os como inertes e proibindo a sua importação. O tema sempre foi encarado como um desafio a ser resolvido pela gestão pública, fato que impulsionou a institucionalização de uma verdadeira responsabilidade solidária dos produtores e revendedores pela logística reversa dos resíduos gerados, por força da Política Nacional dos Resíduos Sólidos, independente de qualquer ação pública.

Nas Comunidades Europeias, desde 1999 foram editadas Diretivas sobre o tema, cujos objetivos eram, pouco a pouco, eliminar o passivo de resíduos de pneus em todos os países integrantes do bloco. A preocupação consistia em evitar não só o descarte inadequado, como 
também impedir que esses resíduos fossem sequer direcionados para os aterros sanitários, visto que, desde 1989, em função da Convenção de Basileia, as CE começaram a tomar ciência de que havia problemas em 20 categorias de resíduos e passaram a investigar o tema. Devido à impossibilidade de enviar os resíduos para o local que, em tese, seria a destinação final adequada - os aterros sanitários -, as CE se viram diante de um desafio ambiental e também econômico, posto que, além de não poderem descartar os resíduos em seus aterros, também se viram impedidas de exportar esse material para o Brasil, um grande mercado consumidor em potencial.

A OMC, em seu Acordo Constitutivo, elege a proteção do meio ambiente como um de seus pilares fundamentais. Não obstante, é cediço que ela não se constitui um órgão ambiental internacional e, portanto, não é no seu bojo que devem ser desenvolvidas discussões em relação a essa temática. Portanto, o meio ambiente não é um assunto discutível por si mesmo no âmbito contencioso da Organização, exceto quando repercute como entrave ao livre-comércio. No caso em tela, o relatório do $\mathrm{OA}$ representou importante marco na jurisprudência da OMC, pois que reverteu todo o entendimento do Painel, para considerar a proteção do meio ambiente justificativa plausível para a restrição brasileira e, assim, elevar a importância dessa questão em meio a uma discussão econômica.

No interior do que se pode chamar de grande embate - Brasil X Comunidades Europeias -, ainda houve outras batalhas, como aquela travada entre as grandes empresas fabricantes de pneus novos e a união das várias pequenas empresas reformadoras e, ainda, entre as organizações ambientais e de direitos humanos, que apresentaram suas petições, e países como o Japão e outros, que também se posicionaram, só que a favor da cassação da medida proibitiva.

Nesse sentido, ao proibir a importação de matérias-primas importadas, de boa qualidade e preços competitivos, o Brasil, na verdade, não só contrariou interesses da indústria local de reforma de pneus, mas também mostrou empenho em resolver um problema que não estava relacionado somente à questão ambiental, mas envolvia um tema de grande responsabilidade - a saúde pública, além de obter, no fim, importante papel internacional ao elevar o peso da discussão ambiental no meio econômico.

Ainda, a opinião pública de modo geral, por meio da repercussão do caso, bem como pela manifestação escrita de várias organizações, teve papel relevante no desenrolar da controvérsia, posto que acompanhou o caso, passo a passo, e se posicionou, por meio do oferecimento de petições, como amicus curiae.

Ao se analisar os posicionamentos de cada parte, vê-se que de fato houve momentos em que a postura de ambas as partes foi contraditória, como quando o Brasil ofereceu justificativas apenas econômicas quando questionado no MERCOSUL; a própria permissão concedida aos países do MERCOSUL era contraditória, posto que estes países poderiam perfeitamente importar das $\mathrm{CE}$ e, a seguir, exportar para o Brasil, pois que não existiriam meios seguros de se garantir que isso não acontecesse; e também quando o Brasil não adotou medidas urgentes para expurgar de seu ordenamento jurídico a Lei 12.381/2005, do Estado do Rio Grande do Sul, flagrantemente inconstitucional, tanto formal, quanto materialmente falando. Ademais, quando não ajuizou, a tempo e modo, a pertinente medida judicial cabível para cassar as liminares judiciais contrárias à Constituição Federal.

No sentido do que se refletiu sobre a questão do MERCOSUL, é importante observar que:

\begin{abstract}
A flexibilização da legislação brasileira face às decisões do Mercosul, apesar de necessárias quando ao esforço de se seguir o princípio constitucional de busca da integração regional na América Latina, enfraquece o esforço do governo (e.g. IBAMA e CONAMA, no âmbito do MMA; DECEX e SECEX junto ao MDIC; e Ministério da Saúde), de manter uma política coerente que proíba a importação de pneus usados e reformados como forma de evitar a acumulação de resíduos tóxicos e poluentes em território nacional, e assim, o escopo de proteção do meio ambiente e saúde pública (KWEITEL; SANCHEZ, 2007, p. 23).
\end{abstract}

As Comunidades Europeias, por sua vez, poderiam ter se conformado com a decisão do Painel, a qual, de modo geral, só lhes trouxe benefícios. Porém, por terem apelado, acabaram por perder em segunda instância, de 
modo que as medidas restritivas brasileiras foram consideradas adequadas e necessárias pela interpretação do Artigo XX, especificamente da alínea "b”.

Por todo o exposto, conclui-se que existem mais evidências a apontar que:

- a argumentação pró-ambiente relativa à imposição das medidas restritivas foi utilizada de modo adequado pelo Brasil, pois que, de fato, é inegável a existência de grande passivo ambiental de pneus no país, bem como os riscos que este pode causar ao meio ambiente e à saúde pública;

- a inexistência de uma forma totalmente segura para destinação dos pneumáticos foi decisiva para o entendimento anterior, posto que se verificou, na prática, que o Brasil não conhece e não dispõe de meios tecnológicos e financeiros para implementar soluções ambientalmente livres de impactos;

- as Comunidades Europeias buscaram a retirada das medidas restritivas a partir do momento em que não puderam mais enviar seus resíduos de pneus para os seus próprios aterros sanitários, por força das suas diretivas sobre a questão, o que fez com que procurassem, seguindo uma lógica de mercado, o Brasil, país em desenvolvimento com a maior frota de veículos do mundo, como receptor desse lixo, sendo que a portaria brasileira estava vigendo no país desde 1991, evidenciando-se, com isso, a continuidade da já reiterada prática utilizada pelos países do primeiro mundo de exportar o lixo indesejável, contradizendo, inclusive, convenções internacionais assinadas, como a Convenção de Basileia;

- a possível alegação de proteção à indústria nacional, que poderia existir em virtude das medidas restritivas, não se sustenta em face do grande número de liminares concedidas às próprias empresas reformadoras nacionais, posto que inexiste no país, e isso é fato alegado pelo próprio Ministério do Meio Ambiente, uma rede logística estruturada de coleta e disponibilização de pneus usados.

Assim, existem elementos suficientes para indicar que a atitude de impor restrições à importação de pneus usados/reformados derivou de interesses ambientais brasileiros, inclusive como repercussão, em solo pátrio, de um mover internacional nesse sentido, e de saúde pública, não se apresentando, assim, elementos suficientes para indicar qualquer favorecimento econômico disfarçado.

\section{Referências}

ASSOCIAÇÃO BRASILEIRADO SEGMENTO DE REFORMADE PNEUS. Cenário da reforma de pneus no Brasil. 2011. Disponível em: <http://www.abr.org.br/dados.html>. Acesso em: 20/12/2011.

ASSOCIAÇÃO NACIONAL DA INDÚSTRIA DE PNEUMÁTICOS. Os pneumáticos no Brasil. 2004. Disponível em: <http://www.anip.com.br/?cont=anip $>$. Acesso em: 20/12/2011.

BRASIL. Ministério da Fazenda. Departamento de Comércio Exterior. Portaria DECEX n. 8, de 13 de maio de 1991. Disponível em: $<$ http://www.legiscenter.com.br/minha_conta/ bj_plus/direito_tributario/atos_legais_federais/portarias/ decex/1991/portaria_08_decex_de_13-05-91.htm>. Acesso em: 10/12/2011.
KWEITEL, Juana; SANCHEZ, Michelle Ratton. Participação da sociedade civil: comércio, saúde e meio ambiente na OMC Comunidades Europeias vs. Brasil: o caso dos pneus. Cadernos Direito GV, São Paulo, v. 4, n. 3, p. 1-42, maio 2007.

LAGARINHOS, Carlos Alberto Ferreira; TENÓRIO, Jorge Alberto Soares. Reciclagem de pneus: discussão do impacto da política brasileira. Engevista, Rio de Janeiro, v. 11, n. 1, 2009. Disponível em: $<$ http://www.uff.br/engevista/1_11Engevista4. pdf $>$. Acesso em: 08/12/2011.

LE PRESTE, Philippe. Ecopolítica internacional. 2. ed. São Paulo: Senac São Paulo, 2005.

LEITE, Carlos Alberto Gonçalves; SERRA, Neusa. Gestão ambiental de pneus inservíveis no Brasil: identificação de fluxos e contribuição para políticas públicas de destinação. In: 
CONGRESO MUNDIAL ISWA 2005: Hacia un Sistema Integral de Gestión de Residuos Sólidos Urbanos, 2005. [Trabalho apresentado]. Buenos Aires, 6-10 nov. 2005.

LIMA, Liana Maria Taborda. A emblemática questão da importação dos pneus usados. In: Ambito Jurídico, Rio Grande, n. 55, 31/07/2008 [Internet]. Disponível em: <http://www. ambito-juridico.com.br/site/index.php?n_link=revista_artigos_leitura\&artigo_id=3053>. Acesso em 10/12/2011.

MINISTÉRIO DO DESENVOLVIMENTO, INDÚSTRIA E COMÉRCIO EXTERIOR. Acordo Constitutivo da OMC. Disponível em: <http://www.mdic.gov.br/arquivo/secex/ omc/acordos/portugues/02estabeleceomc.pdf $>$. Acesso em: $08 / 12 / 2011$.

MINISTÉRIO DO MEIO AMBIENTE. Pneus: problema ambiental e de saúde pública. s/d. Disponível em: $<$ http://www. mma.gov.br/sqa/prorisc/index.cfm?submenu=10>. Acesso em: 10/12/2011.

MOROSINI, Fabio. A guerra dos pneus. Casoteca Latino-Americana de Direito e Política Pública, 2006. Disponível em: $<$ http://www.faap.br/faap juris/pdf/Narrativafinal12-1.09.06-AGuerradosPneus.pdf $>$. Acesso em: 10/12/2011.

MOTTA, Flavia Gutierrez. A cadeia de destinação dos pneus inservíveis - o papel da regulação e do desenvolvimento tecnológico. Ambiente \& Sociedade, Campinas, v. XI, n. 1, 2008. Disponível em: $<$ http://www.scielo.br/pdf/asoc/v11n1/11.pdf $>$. Acesso em: 11/12/2011.

PEREIRA, Maria Auxiliadora. A difícil equação entre comércio e meio ambiente: o caso da proibição de pneus usados e remoldados da União Europeia. 2011. 118 p. Dissertação (Mestrado em Desenvolvimento Sustentável) - Centro de Desenvolvimento Sustentável, Universidade de Brasília, Brasília, 2011.

Recebido em 20 de agosto de 2012. Aceito em 20 de março de 2013. Publicado em junho de 2013. 